\title{
Short Communication: \\ Leaf architectural analysis of taxonomically confusing coffee species: Coffea liberica and Coffea liberica var. dewevrei
}

\author{
ALCONA MAE P. BALTAZAR ${ }^{1,2, \boldsymbol{v}}$, INOCENCIO E. BUOT, JR. ${ }^{2,3}$ \\ ${ }^{1}$ Department of Biological Sciences, Cavite State University. Main Campus, Indang, Cavite 4122, Philippines. Tel.: +63-935-879 2359, \\ vemail: apbaltazar@up.edu.ph \\ ${ }^{2}$ Institute of Biological Sciences, College of Arts and Sciences, University of the Philippines Los Baños. College, Batong Malake, Los Baños, \\ Laguna 4031, Philippines \\ ${ }^{3}$ Faculty of Management and Development Studies, University of the Philippines-Open University. College, Batong Malake, Los Baños 4031, \\ Laguna, Philippines
}

Manuscript received: 29 March 2019. Revision accepted: 9 May 2019

\begin{abstract}
Baltazar AMP, Buot JrIE. 2019. Short Communication: Leaf architectural analysis of taxonomically confusing coffee species: Coffea liberica and Coffea liberica var. dewevrei. Biodiversitas 20: 1560-1567. Coffee is considered as one of the most important crops. The Philippines is known to produce four coffee varieties namely: Arabica (Coffea arabica), Robusta (Coffea canephora), Excelsa (Coffea liberica var. dewevrei) and Liberica (Coffea liberica). Further, the taxonomy of C. liberica and C. liberica var. dewevrei is still unclear. Since its earliest publication, the relationship of the two taxa have been confusing many taxonomists and also farmers. The status of the two confusing taxa are still under discussions due to contradicting evidence inferred from morphological and molecular data. The two taxa have been claimed as separated species but the markers are considered inconsistent in the field. This study has tried to examine the leaf architectural characters of both species as these have been known to be genetically fixed. Leaf samples of each species including $C$. canephora (outgroup) were collected and examined. Results showed that the two taxa were found to be different in laminar size, domatia distribution, major secondary attachment, and intercostal tertiary veins. Cluster analysis revealed that they are grouped separately. However, the rank of $C$. liberica var. dewevrei cannot be decided yet until further taxonomic study, particularly on the anatomy and distribution pattern of domatia, is completed.
\end{abstract}

Keywords: Coffea, Excelsa, leaf architecture, leaf venation, Liberica

\section{INTRODUCTION}

The taxonomic work on genus Coffea L. has been actively progressing since the late 1980's resulting in a total of 103 species and seven infraspecific taxa to date (Davis et al. 2006). The placement of species under this genus was defined by morphological, biochemical, molecular analyses, etc. (Orozco-Castillo et al. 1996; Roos et al. 1997; Chinnappa and Warner 2008; Davis and Rakotonasolo 2008). However, with these evidence, some infraspecific taxa are still facing confusion up to this day. For example, is the case of Coffea liberica W. Bull ex Hiern and Coffea liberica var. dewevrei (De Wild. \& T.Durand) Lebrun which has been designated as two separate species.

Coffea liberica, the currently accepted name, was validly published by William Philip Hiern in 1876 and has six synonyms (IPNI 2005; The Plant List 2013). This species is classified under family Rubiaceae and has one infraspecific taxon in the name of $C$. liberica var. dewevrei. This infraspecific taxon was first described and published by Émile Auguste Joseph De Wildeman and Théophile Alexis Durand as $C$. dewevrei in 1899. It was later published and accepted as $C$. liberica var. dewevrei by Jean-Paul Antoine Lebrun in 1941 along with $C$. liberica var. liberica which is now a synonym of $C$. liberica.
Since its publication in 1941, there are several confusions regarding the identity of the two taxa. In the study of Bridson (1988) and unpublished work of Noirot and Maurin, morphological and molecular evidence were found to support the two as separate varieties (Davis et al. 2006). However, N'Diaye et al. (2005) stated that they are more distinguished than botanical varieties as supported by their differences in morphological traits, molecular markers, and hybrid fertility. The genes involved in this separation are not yet elucidated and in the study by Cao et al. (2014), $r b c \mathrm{~L}$ and $m a t \mathrm{~K}$ genes were found to provide clustered data and cannot be used to delineate the two taxa. However, they have found out that leaf morphometric characters were effective in defining the two taxa.

Coffea liberica and C. liberica var. dewevrei are known in the Philippines as "Barako" and "Excelsa" coffees respectively (Philippine Coffee Board 2018). After the coffee rust infection of coffee farms in Batangas, Philippines in 1889, unidentified seedlings were transferred to Cavite. This initiated the local coffee farmers to devise their own way of identifying the coffee varieties through observance of fruit density and leaf shapes. However, farmers are still confused with Excelsa and Liberica as both possess inconsistent morphological markers and fruit density is highly affected by environment. Also, fruits and flowers are not always available in the field. With this 
problem left unresolved, the taxonomic confusion will remain as a threat to the quality of pure coffee beans and coffee industry.

In the absence of reproductive structures, leaf characters can be used in resolving taxonomic confusion. Each plant species has their own leaf fingerprint that may provide morphological, anatomical and biochemical evidence to support the identity of the species. One of this evidence is found in leaf venation pattern which is considered as a taxonomic tool because its primary characteristics are genetically fixed (Roth-Nebelsick et al. 2001).

In this study, leaf architectural analysis was used to differentiate $C$. liberica and $C$. liberica var. dewevrei. It was also aimed to provide an alternative way of determining the identity of the unclear coffee variety through difference in leaf architectural characters and hopefully address the confusion between the two taxa.

\section{MATERIALS AND METHODS}

\section{Sampling and preparation of plant materials}

The plant materials were obtained from the living coffee accessions of Cavite State University-National Coffee Research, Development \& Extension Center (CvSU-NCRDEC) in Cavite, Southern Luzon, Philippines. Only one tree for $C$. liberica was sampled because it was the only Liberica tree validated and approved by the National Seed Industry Council (NSIC) in the Philippines. The tree was 72 months old as of the date of registration and was tagged as NSIC 2007 Cf-L 01. However, for the case of $C$. liberica var. dewevrei, none has been registered yet at NSIC so instead, leaf samples were gathered from the identified tree by researchers in National Coffee Research Development and Extension Center (NCRDEC). To ensure that the leaf samples are not from unverified coffee species, sampling was only limited to the aforesaid identified trees (Figure 1).

A total of 20 leaf samples from each tree were obtained. To represent the outgroup, leaf samples from $C$. canephora were also acquired. The first fully expanded leaves from the terminal part of the branch were chosen. The leaves were soaked in $5 \% \mathrm{NaOH}$ and then boiled until the mesophyll tissues of the leaves were soft (Mishra et al. 2010). The soft leaf tissues were carefully brushed to reveal the veins underneath. The leaf skeletons were soaked in hypochlorite to eliminate the pigments. Finally, the leaf skeletons were pressed until completely dried (Figure 2). However, C. canephora leaves were not skeletonized because its mesophyll tissues were covered with a very thick cuticle. Leaf skeletons were deposited in Plant Systematics Laboratory Herbarium, Institute of Biological Sciences, University of the Philippines Los Baños, College, Laguna with accession numbers 6878 (C. liberica), 6879 (C. liberica var. dewevrei) and 6880 (C. canephora).

\section{Leaf measurement and characterization of leaf venation patterns}

The leaf width and length were measured using a ruler and a protractor was used for measuring angles. The leaves were observed under a dissecting microscope (Euromex Edu Blue Series) for the analysis of smaller vein patterns. The leaf characters were divided into two categories: laminal and venation characters. The laminal characters included leaf attachment, leaf arrangement, leaf organization, laminar width, laminar length, laminar area, laminar size, laminar shape, medial symmetry, margin type, special margin features, apex angle, apex shape, base angle, base shape, and domatia distribution. On the other hand, venation characters included primary vein framework, major secondary vein framework, major secondary spacing, major secondary angle, major secondary attachment, intercostal tertiary vein fabric, epimedial tertiaries, exterior tertiary course, quarternary vein fabric, quarternary vein fabric, areolation and freely ending veinlets. The terminologies used to describe and classify leaf characters were based on the Manual of Leaf Architecture by Ellis et al. (2009).

\section{Statistical analysis}

To investigate the venation patterns and dissimilarities of $C$. liberica, C. liberica var. dewevrei, and C. canephora (outgroup), a total of 28 leaf characters were observed for each of the 20 leaf samples per individual species. This examination resulted in a total of 1,680 data sets. Since the terminologies from the Manual of Leaf Architecture were qualitative, each leaf character was designated with a numerical value. These values were entered in statistical software to do cluster and ordination analyses. Cluster analysis was done for grouping the species into clusters of similar leaf architectural traits and to illustrate their relationships. Two algorithms were used in this analysis namely, unweighted paired group average (UPGMA) and single linkage (nearest neighbor) both computed with Euclidean similarity index. All computations had bootstrap value of 1000. In addition, ordination analysis using Principal Coordinates Analysis (PCoA) was also done to demonstrate the individual differences of the Coffea species. PAST (Paleontological Statistical Software) software by Hammer et al. 2001 was used for the statistical analysis.

\section{RESULTS AND DISCUSSION}

The leaves of $C$. liberica and $C$. liberica var. dewevrei shared a lot of similar laminal features (Table 1) which further contributes to their taxonomic confusion. Coffea spp. are known for their shrub or small tree habit, with simple, petiolate and opposite leaves which were observed in all leaf samples including the outgroup. All leaf samples of $C$. liberica and $C$. liberica var. dewevrei were elliptic while $C$. canephora samples had elliptic-obovate shape. Some leaf samples of $C$. liberica and $C$. liberica var. dewevrei were observed to exhibit asymmetrical leaves which were said to be influenced by correct auxin transport under a specific environment condition (Scarpella et al. 2010). Coffea liberica and C. liberica var. dewevrei both had entire and undulate margin, acute and convex apex and, acute and straight base. Coffea canephora leaves also exhibited the same features except for its acuminate apex. 
However, the laminar size of $C$. liberica differ from $C$. liberica var. dewevrei and $C$. canephora because of few larger leaf samples that included under microphyll category $\left(18,225-164,025 \mathrm{~mm}^{2}\right)$. Another dissimilar laminal feature between the two Coffea leaves was the distribution of domatia which harbor small insects in its hollow structure. The domatia of $C$. liberica was consistently found to be distributed along the midrib and the secondary veins while that of $C$. liberica var. dewevrei was along the midrib only (Figure 3). Further, domatia in four different Coffea species were reported to have varying trichome structures and this can have taxonomic implications (Balinado 2018, pers. com.). However, the formation and distribution of domatia in Coffea species could not be considered taxonomic character. As of now, more studies on domatia in other localities and its association with mites or other insects would be urgent. The production of domatia can be influenced by several factors including the presence of beneficial mites (O'Connell et al. 2015).

On the other hand, the venation patterns of $C$. liberica, C. liberica var. dewevrei leaves also exhibited some similarities. Both have pinnate primary vein; simple brochidodromous, regularly spaced and uniformly angled secondary veins; alternate percurrent epimedial tertiary veins; looped exterior tertiary veins; irregularly reticulate quarternary veins; freely ramifying quarternary veins; moderately developed areolation and dendritic freely ending veinlets (Figure 4 and Table 2). This number of similar features even in higher vein orders makes the two leaves indistinguishable from each other. Conversely, $C$. canephora displayed many dissimilar venation patterns from the confusing species. It had opposite percurrent intercostal and epimedial tertiaries, irregularly reticulate quarternary veins and good areole development.

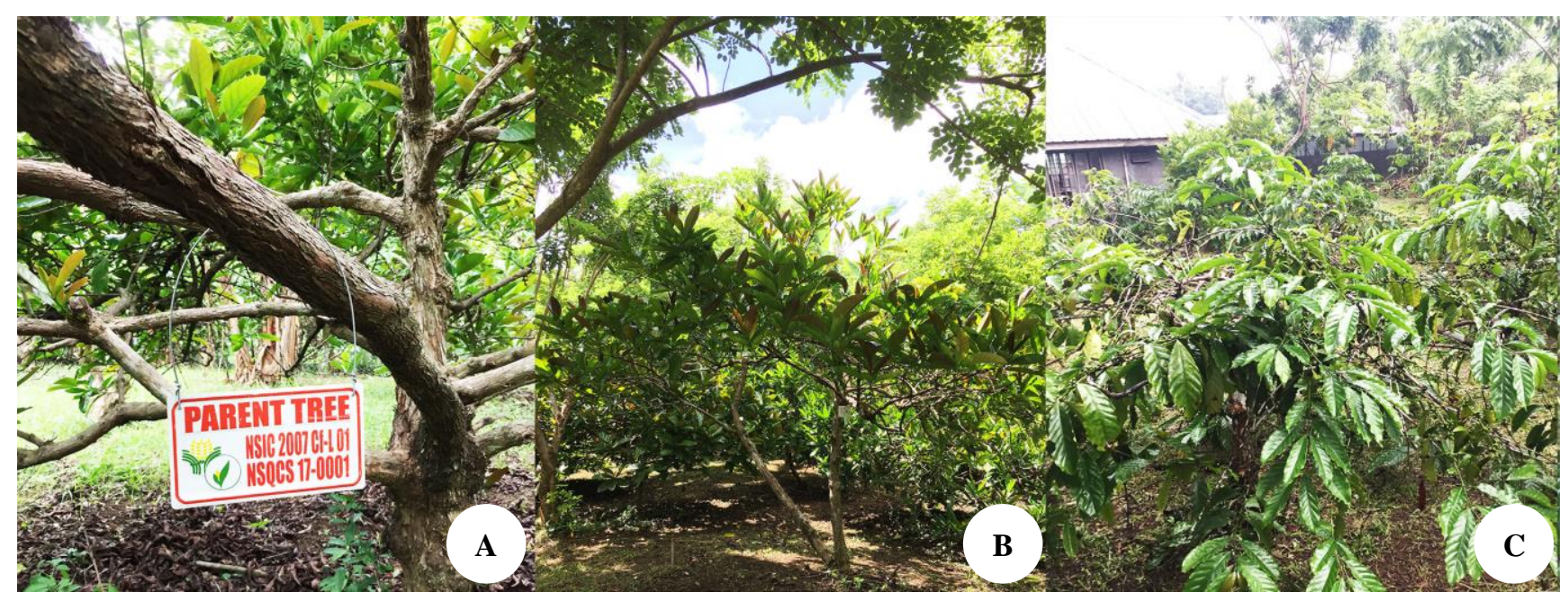

Figure 1. Representative trees of A. C. liberica, B. C. liberica var. dewevrei, C. C. canephora. (Photograph: A.M.P. Baltazar)

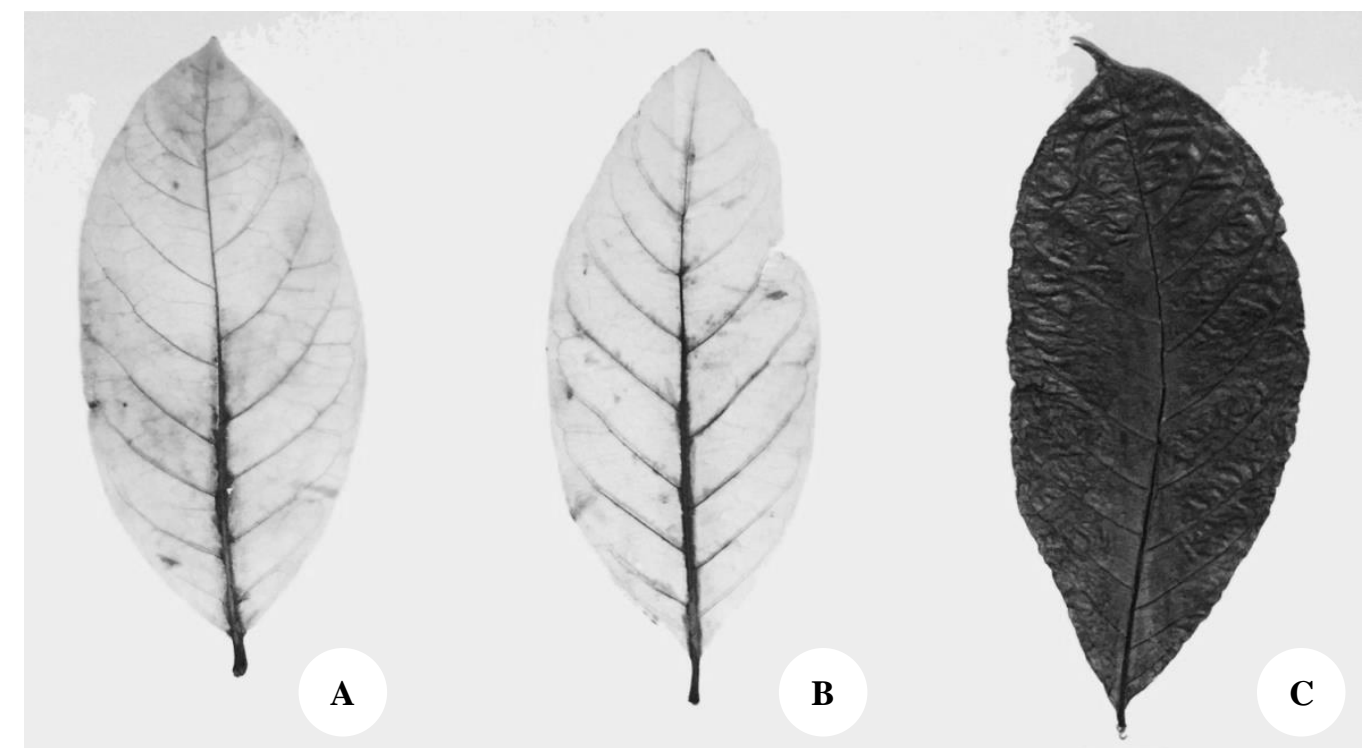

Figure 2. Leaf samples of A. C. liberica, B. C. liberica var. dewevrei and C. C. canephora (Photograph: A.M.P. Baltazar) 


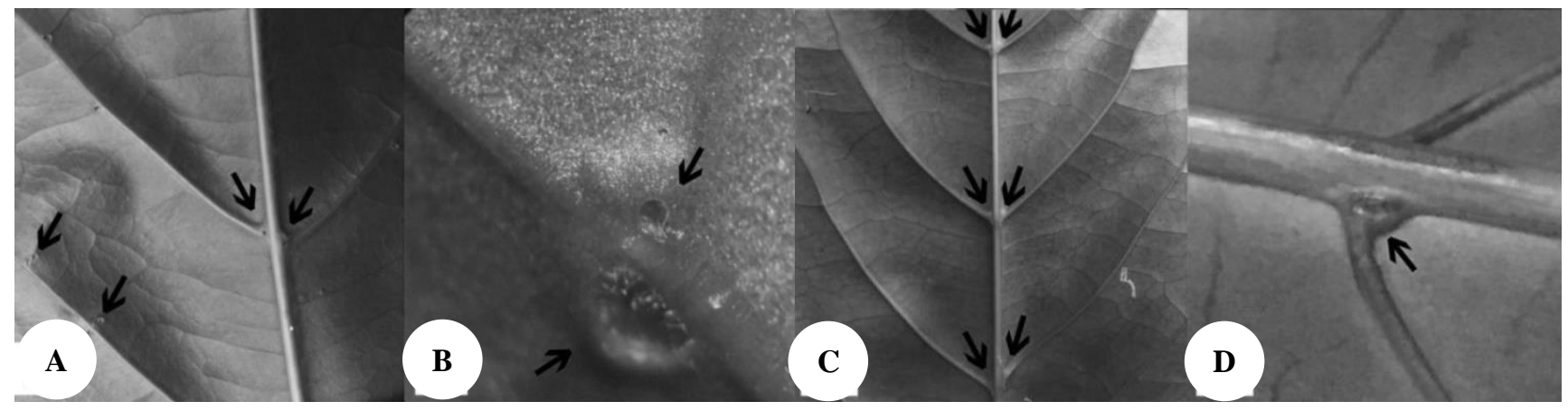

Figure 3. Domatia distribution on the blade of A-B. C. liberica and C-D) C. liberica var. dewevrei. (Photograph: A.M.P. Baltazar)

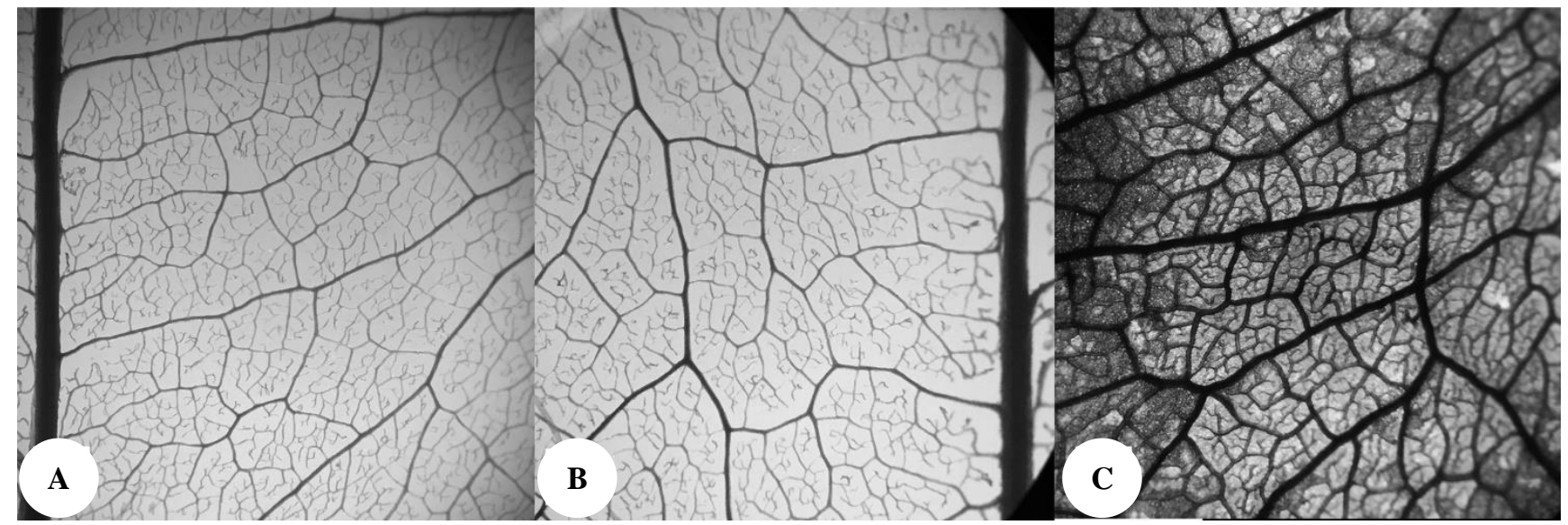

Figure 4. Higher vein orders of A. C. liberica, B. C. liberica var. dewevrei, and C. C. canephora. (Photograph: A.M.P. Baltazar)

Table 1. General laminal characters of $C$. liberica and $C$. liberica var. dewevrei

\begin{tabular}{llll}
\hline Laminal characters & C. liberica & C. liberica var. dewevrei & C. canephora \\
\hline & & & \\
Leaf attachment & Petiolate & Petiolate & Petiolate \\
Leaf arrangement & Opposite & Opposite & Opposite \\
Leaf organization & Simple & Simple & Simple \\
Laminar width & $71.5-120 \mathrm{~mm}$ & $63.5-92.5 \mathrm{~mm}$ & $60.5-97 \mathrm{~mm}$ \\
Laminar length & $164-267 \mathrm{~mm}$ & $168-212 \mathrm{~mm}$ & $160-239 \mathrm{~mm}$ \\
Laminar area & $8794.5-24,030 \mathrm{~mm}^{2}$ & $8001-14,707.5 \mathrm{~mm}^{2}$ & $7260-17837.25 \mathrm{~mm}^{2}$ \\
Laminar size & Mesophyll-microphyll & Mesophyll & Mesophyll \\
Laminar shape & Elliptic & Elliptic & Elliptic-Obovate \\
Medial symmetry & Symmetrical-asymmetrical & Symmetrical-asymmetrical & Symmetrical \\
Margin type & Entire & Entire & Entire \\
Special margin features & Undulate & Undulate & Undulate \\
Apex angle & Acute & Acute & Acute \\
Apex shape & Convex & Convex & Acuminate \\
Base angle & Acute & Acute & Acute \\
Base shape & Straight & Straight & Straight \\
Domatia distribution & Along midrib and secondary veins & Along midrib & Along midrib \\
& & & \\
\hline
\end{tabular}


Table 2. General leaf venation patterns of $C$. liberica and $C$. liberica var. dewevrei

\begin{tabular}{|c|c|c|c|}
\hline Venation characters & C. liberica & C. liberica var. dewevrei & C. canephora \\
\hline Primary vein framework & Pinnate & Pinnate & Pinnate \\
\hline Major secondary vein framework & Simple brochidodromous & Simple brochidodromous & Simple brochidodromous \\
\hline Major secondary spacing & Regular & Regular & Regular \\
\hline Major secondary angle & Uniform & Uniform & Uniform \\
\hline Major secondary attachment & $\begin{array}{l}\text { Decurrent-proximal } \\
\text { secondaries decurrent }\end{array}$ & Decurrent & $\begin{array}{l}\text { Proximal secondaries } \\
\text { decurrent }\end{array}$ \\
\hline Intercostal tertiary vein fabric & Irregular reticulate & Mixed percurrent & Opposite percurrent \\
\hline Epimedial tertiaries & Alternate percurrent & Alternate percurrent & Opposite percurrent \\
\hline Exterior tertiary course & Looped & Looped & Looped \\
\hline Quarternary vein fabric & Irregular reticulate & Irregular reticulate & Irregular reticulate \\
\hline Quarternary vein fabric & Freely ramifying & Freely ramifying & Irregular reticulate \\
\hline Areolation & Moderate development & Moderate development & Good development \\
\hline FEVs & Dendritic & Dendritic & Dendritic \\
\hline
\end{tabular}

Table 3. Opposing leaf architectural characters of $C$. liberica and C. liberica var. dewevrei

\begin{tabular}{llll}
\hline Leaf characters & C. liberica & C. liberica var. dewevrei & C. canephora \\
\hline Laminar size & Mesophyll-macrophyll & Mesophyll & Mesophyll \\
Domatia distribution & Along midrib and secondary veins & Along midrib & Along midrib \\
Major secondary attachment & Decurrent-proximal secondaries decurrent & Decurrent & Proximal secondaries decurrent \\
Intercostal tertiary vein fabric & Irregular reticulate & Mixed percurrent & Opposite \\
& & &
\end{tabular}

However, two venation patterns were found to be different between $C$. liberica and $C$. liberica var. dewevrei upon close examination. The major secondary veins of some $C$. liberica leaf samples were observed to be decurrently exhibited by asymptotically attached secondaries to the primary vein. Some leaf samples also had proximally decurrent secondaries which were characterized by both having decurrent proximal secondaries and excurrent distal secondaries. On the other hand, the secondary veins of $C$. liberica var. dewevre $i$ were decurrent all throughout. Another difference was the irregularly reticulate arrangement of $C$. liberica tertiary veins exhibited by the formation of irregular polygons shaped by its variously angled tertiary veins. Conversely, C. liberica var. dewevrei has mixed percurrent tertiary veins demonstrated by the presence of both branched and unbranched tertiary veins crossing two adjacent secondaries. The leaf architectural characters that separated C. liberica and C. liberica var. dewevrei were summarized in Table 3.

A generated dendrogram from UPGMA algorithm illustrated that $C$. liberica, $C$. liberica var. dewevrei and $C$. canephora (outgroup) were distinct from each other even with slightly dissimilar leaf characters included in the analysis (Figure 5). C. liberica and C. liberica var. dewevrei were separated from $C$. canephora (outgroup) at distance 2.9 indicating their strong dissimilarities in terms of laminar shape, medial symmetry, apex shape, intercostal and epimedial tertiaries, quarternary veins and areoles. At distance $1.75, C$. liberica and $C$. liberica var. dewevrei were split into two separate groups, also suggesting dissimilarity between the two taxa in terms of laminar size, domatia distribution, major secondary vein attachment, and intercostal tertiary veins. All 20 leaf samples of $C$. liberica clustered together although the dendrogram showed several branching within the group. On the other hand, $C$. liberica var. dewevrei leaf samples showed higher degree of similarity among leaf samples exhibited by less branched clades. Moreover, single linkage clustering approach revealed the same trend as UPGMA dendrogram with minor difference in distance (Figure 6). Meanwhile, Figure 7 showed that $C$. liberica, $C$. liberica var. dewevrei and $C$. canephora landed on different axes suggesting that they are dissimilar from each other.

However, both analyses on the dissimilarity between $C$. liberica and $C$. liberica var. dewevrei in terms of leaf architecture are not enough to decide on the rank that should be employed on the latter. Imprecision in the use of infraspecific ranks such as subspecies and variety has been observed for the past periods but generally, apart from morphological evidence, evolutionary and ecogeographical confirmations should be taken into the picture to understand the true relationship of the two taxa (Hamilton and Reichard 1992). It is suggested that molecular markers 
for leaf architecture especially on leaf venation of $C$. liberica and $C$. liberica var. dewevrei must be studied to reveal the alignment of morphological and molecular evidence. Furthermore, the consistency of domatia distribution on the leaves of $C$. liberica and $C$. liberica var. dewevrei must be studied in larger number of samples under different environmental conditions. If the stability of this character is confirmed, it can be used practically by farmers to rapidly identify the species.

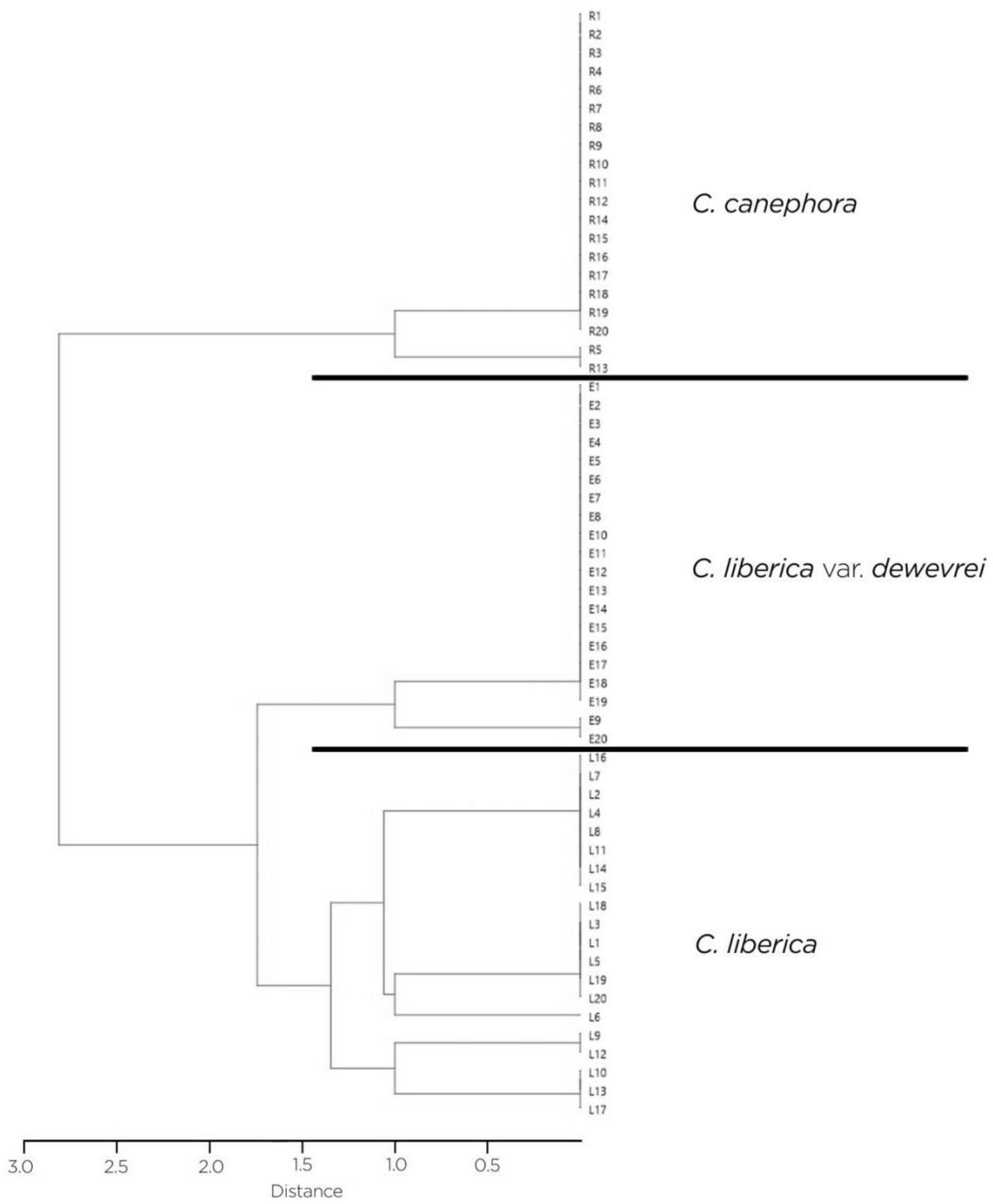

Figure 5. Dendrogram using UPGMA clustering approach using Eucledian as the distance measure. Bootstrap value: 1000 


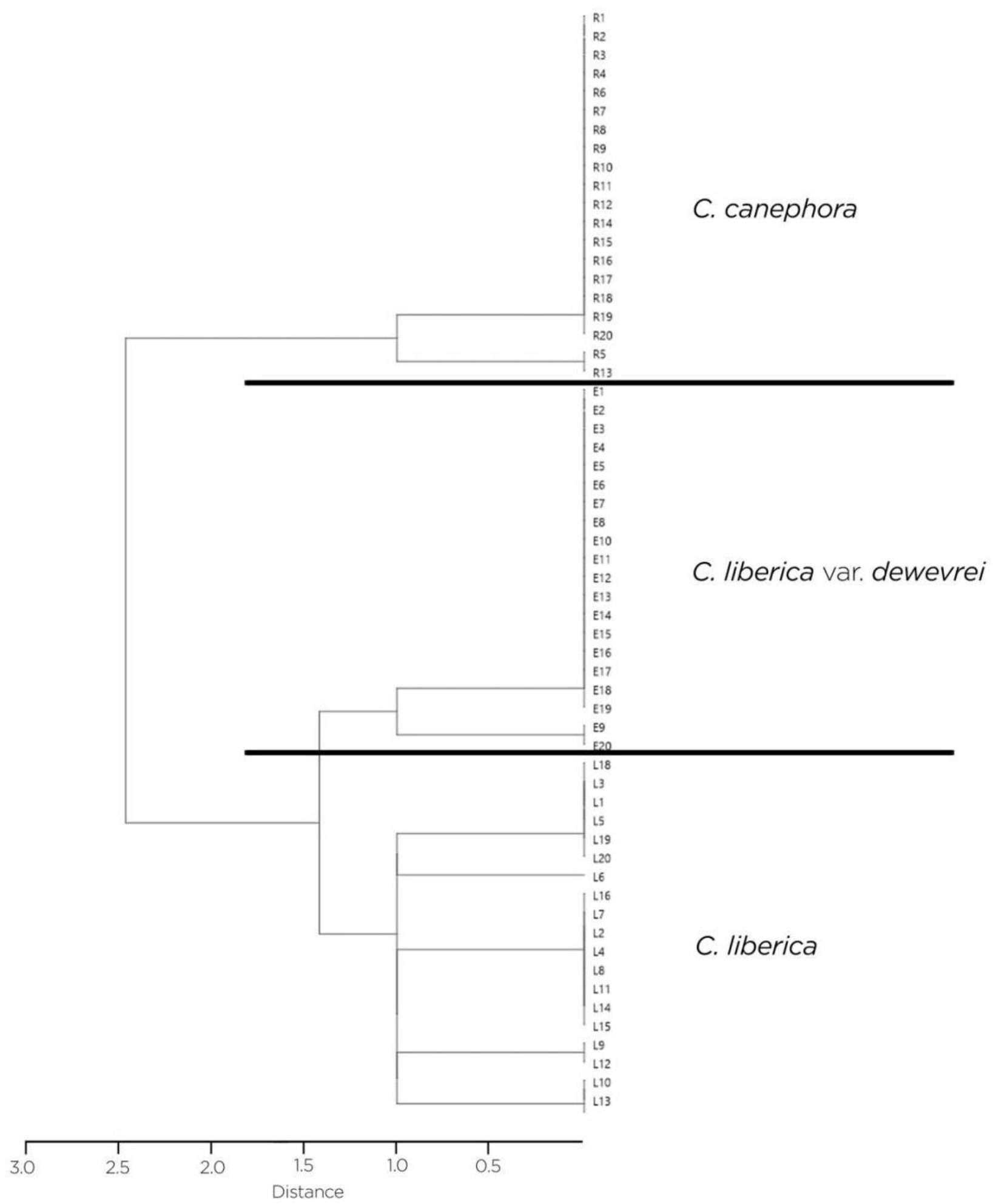

Figure 6. Dendrogram using single linkage clustering approach using Eucledian as the distance measure. Bootstrap value: 1000

In conclusion, the two confusing taxa, of $C$. liberica and $C$. liberica var. dewevrei subjected to leaf architectural analysis were found to be different in terms of laminar size, domatia distribution, secondary vein attachment, and intercostal tertiary vein category. Cluster and ordination analyses revealed the dissimilarity of the two taxa. While results showed the difference between $C$. liberica and $C$. liberica var. dewevrei, further studies should be taken into consideration to confirm the rank of $C$. liberica var. dewevrei. It is also recommended to confirm the consistency and stability of these leaf architectural traits under different environmental conditions. This is the first time that leaf architectural evidence has been used to assess the difference between $C$. liberica and $C$. liberica var. dewevrei and their taxonomic significance. 


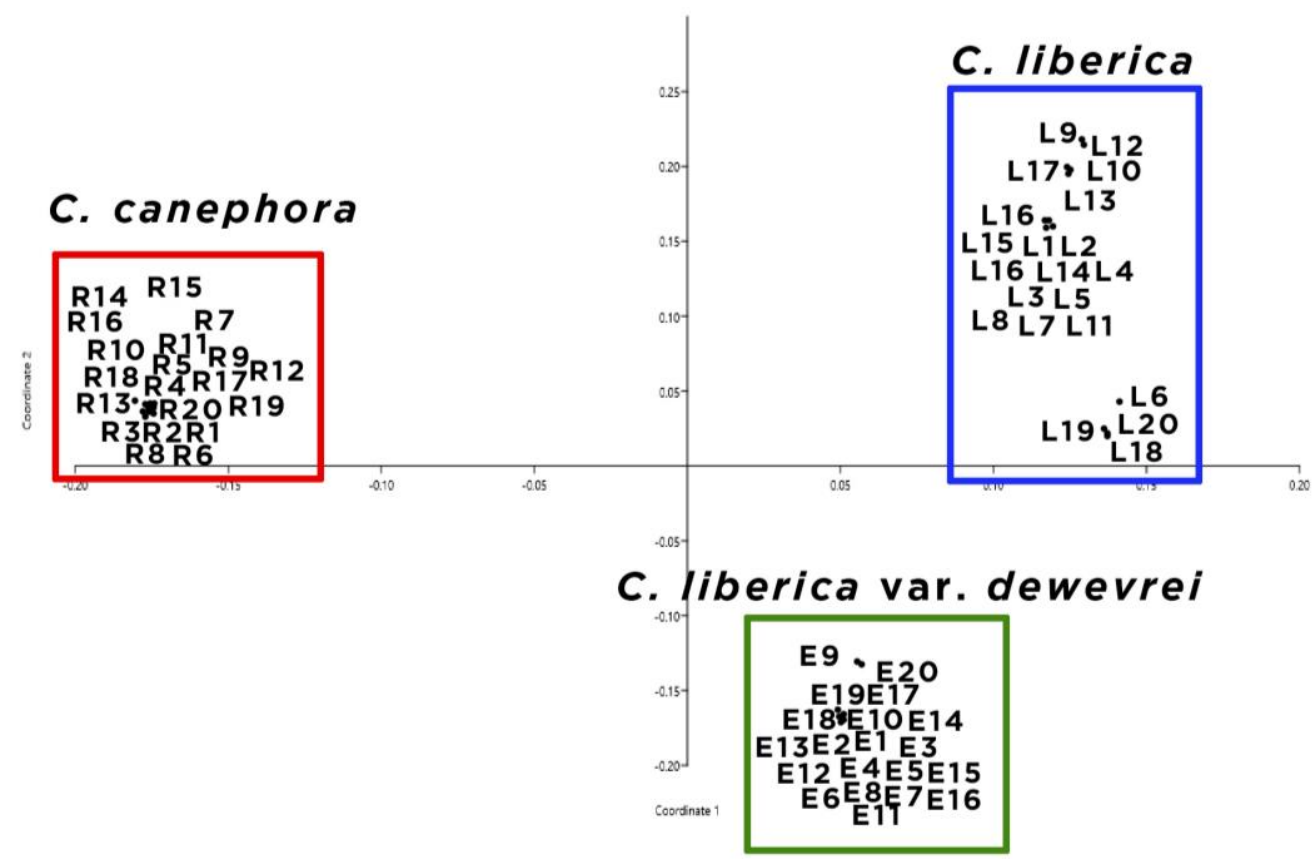

Figure 7. Principal Component Analysis (PCoA) on C. liberica, C. liberica var. dewevrei and C. canephora (outgroup)

\section{ACKNOWLEDGEMENTS}

The authors would like to thank the National Coffee Research Development and Extension Center (NCRDEC) of Cavite State University, Philippines for providing the leaf samples used; Dr. Miriam D. Baltazar, director of NCRDEC, for communicating the information about the current status of Coffee and allowing the author to conduct the study in their laboratory.

\section{REFERENCES}

Cao EP, Constantino-Santos DM, Ramos LAP, Santos BS, Quilang JP, Mojica RM. 2014. Molecular and morphological differentiation among Coffea (Rubiaceae) varieties grown in the farms of Cavite Province, Philippines. Philippine Sci Lett 7 (2): 387-397.

Chinnappa CC, Warner BG. 2008. Pollen morphology in the genus Coffea (Rubiaceae) and its taxonomic significance. Bot J Linnean Soc 83 (3): 221-236. DOI: DOI: 10.1111/j.1095-8339.1981.tb00347.x

Davis AP, Govaerts R, Bridson DM, Stoffelen P. 2006. An annotated taxonomic conspectus of the genus Coffea (Rubiaceae). Bot J Linnean Soc 152 (4): 465-512. DOI: 10.1111/j.1095-8339.2006.00584.x

Davis AP, Rakotonasolo F. 2008. A taxonomic revision of the baracoffea alliance: nine remarkable Coffea species from western Madagascar. Bot J Linnean Soc 158 (3): 355-390. DOI: 10.1111/j.10958339.2008.00936.x

Ellis B, Daly DC, Hickey LJ, Johnson KR, Mitchell JD, Wilf P, Wing SL. 2009. Manual of Leaf Architecture. New York Botanical Garden Press, Ithaca, New York.

Hamilton CW, Reichard SH. 1992. Current practice in the use of subspecies, variety, and forma in the classification of wild plants. Taxon 41 (3): 485. DOI: 10.2307/1222819
Hammer $\varnothing$, Harper DAT, Ryan PD. 2001. Past: Paleontological statistics software package for education and data analysis. Palaeontologia $\begin{array}{llll}\text { Electronica } & 4 & \text { (1). http://palaeo- }\end{array}$ electronica.org/2001_1/past/issue1_01.htm

Mishra MK, Padmajyothi D, Prakash NS, Ram AS, Srinivasan CS, Sreenivasan MS. 2010. Leaf architecture in Indian coffee (Coffea arabica L.) cultivars and their adaptive significance. World J Fungal Plant Biol 1 (2): 37-41.

N'Diaye A, Poncet V, Louarn J, Hamon S, Noirot M. 2005. Genetic differentiation between Coffea liberica var. liberica and C. liberica var. dewevrei and comparison with $C$. canephora. Pl Syst Evol 253: 95-104. DOI: 10.1007/s00606-005-0300-1

O'Connell DM, Monks A, Dickinson KJ, Lee WG. 2015. Is domatia production in Coprosma rotundifolia (Rubiaceae) induced by mites or foliar pathogens?. N Z J Ecol 39 (2): 214-220.

Orozco-Castillo C, Chalmers KJ, Powell W, Waugh R. 1996. RAPD and organelle-specific PCR re-affirms taxonomic relationships within the genus Coffea. Plant Cell Rep 15 (5): 337-341. DOI: 10.1007/BF00232367.

Philippine Coffee Board. 2018. Our Coffee Heritage. Published on the internet: http://philcoffeeboard.com/philippine-coffee [25 June 2018].

Roos BD, Weg GV, Urgert R, Bovenkamp PV, Charrier A, Katan MB. 1997. Levels of cafestol, kahweol, and related diterpenoids in wild species of the coffee plant Coffea. J Agric Food Chem 45 (8): 3065 3069. DOI: $10.1021 /$ jf9700900.

Roth-Nebelsick A, Uhl D, Mosbrugger V, Kerp H. 2001. Evolution and function of leaf venation architecture: A review. Ann Bot 87 (5): $553-$ 566. DOI: $10.1006 /$ anbo.2001.1391.

Scarpella E, Barkoulas M, Tsiantis, M. 2010. Control of leaf and vein development by auxin. Cold Spring Harbor Perspect Biol 2 (1). DOI: 10.1101/cshperspect.a001511.

The International Plant Names Index. 2005. Published on the Internet http://www.ipni.org [5 July 2018].

The Plant List. 2013. Version 1.1. Published on the Internet: http://www.theplantlist.org [25 June 2018]. 